\title{
VSOP-ohjelma etenee
}

\author{
Tytti Liinakoski \\ Vapaan sivistystyön osaaminen ja pätevyys -ohjelman \\ (VSOP) kohteina ovat vapaan sivistystyön omat \\ työntekijät, siis kansanopistoväki sekä kansalais- \\ opistojen ja opintokeskusten työntekijät, heidän \\ pätevyytensä päivitys ja ammattitaidon nosto.
}

Vapaan sivistystyön osaaminen ja pätevyys -ohjelma (VSOP) on suomalaisen vapaan sivistystyön laajin yhtenäinen kehittämishanke. Hanke lähti liikkeelle Vapaan sivistystyö yhteisjärjestön aloitteesta vuonna 1999. Toimintakaudeksi määriteltiin sittemmin 1999-2004 ja se sai kolmiosaisen muodon:

1 visio

1 tutkimus

1 koulutus

Suunnitelmissa oli laajamittainen kehittämisohjelma koko vapaan sivistystyön opetus- ja suunnitteluhenkilöstön kouluttamiseksi. Eri osioilla on toisiaan tukevat tehtävät. Hanketta on tuettu Opetusministeriön ja sittemmin myös Opetushallituksen myöntämillä varoilla. Ohjelma kohdistuu kansanopistojen, kansalais- ja työväenopistojen, opintokeskusten, kesäyliopistojen ja neuvontajärjestöjen henkilöstöön.

\section{Koulutusta koko työyh te is ölle}

VSOP-ohjelman keskeisimpänä osiona voidaan pitää henkilöstön osaamisen kehittämistä. Vapaan sivistystyön identiteetin säilyttämiseksi on katsottu tarpeelliseksi rakentaa mahdollisuuksia opettajan pätevyyden hankkimiseen ja työyhteisöjen kehittämiseeen.

VSOP-ohjelmassa pyritään luomaan opintoja, jot- ka mahdollistavat laaja-alaisen yhteisöllisen kehittymisen yksilöllisten opintojen ohella. VSOPohjelman koulutus onkin käynnistynyt 10 opintoviikon laajuisilla Yhteisöllisyysopinnoilla. Opintojen lähtökohtana on työyhteisössä käytävä keskustelu siitä, mitä halutaan kehittää ja mikä on kunkin työyhteisön oma tulevaisuuden visio. Näin opinnot kytkeytyvät kiinteästi myös vision rakentamisprosessiin. Painotuksen ollessa juuri yhteisöllisyydessä opinnot on suunnattu kaikille työyhteisön jäsenille. Yhteisöllisyysopintojen keskeisiä teemoja ovat paikallinen asiantuntijuus ja asiantuntijuuden jakaminen, muutos, yksilöja yhteisötason osaaminen ja laatu. Samalla yhteisöllisyysopinnot ovat eräs väylä, jolla voi täydentää opettaja- tai kouluttajaopintoja. Erityisesti opettajan pätevyyttä tukevia teema-alueita koulutuksessa ovat opettajuus ja muuttuvat toimintaympäristöt, kohtaaminen ja vuorovaikutus työyhteisöissä ja oman työn tutkiminen ja kehittäminen.

Yhteisöllisyysopinnot käynnistyvät syksyllä 2000 pilottihankkeiden voimin. Koulutuksen toteuttajina ovat Helsingin, Lapin, Jyväskylän ja Tampereen yliopistot, Åbo Akademi, Humanistinen ammattikorkeakoulu ja Yrkeshögskolan Sydväst. Opintoihin osallistuu pilottivaiheessa hieman yli 200 vapaan sivistystyön parissa toimivaa henkilöä. Yhteisöllisyysopinnoissa korostuu prosessinomaisuus. Tarjolla ei ole tarkkoja ja ennalta määriteltyjä koulutuspaketteja, vaan koulutuksen 
suunnittelu jatkuu koko koulutuksen ajan. Jokaisella pilotilla on osallistujien omat lähtökohdat ja tarpeet huomioiva ohjelma. Yhteisöllisyysopinnoissa työyhteisöt sekä yksilöt asettavat itse tavoitteensa. Yhteisöllisyysopintojen päämäärä on kuitenkin selkeä: vahvistaa vapaan sivistystyön organisaatioiden asemaa muuttamalla visiot päteviksi toimintamalleiksi. Tämä prosessi ei voi olla ulkoa johdettu, vaan osallistujien itsensä luoma. Tarkoituksena on kehittää vapaan sivistystyön oppilaitoksista oppivia yhteisöjä, jotka pystyvät vastaamaan ajan asettamiin vaatimuksiin.

\section{Vapaan sivistysyön tutkimuksen elvyttäminen}

Vapaan sivistystyön suuntautuneen tutkimuksen vähäisyys on kiinnittänyt huomiota. Vapaaseen sivistystyöhön ei ole muodostunut selkeää tiedeyhteisöä, joka edistäisi osaltaan alaan kohdistuvan tutkimuksen jatkuvuutta. Yksi VSOP-ohjelman tarkoitus onkin myös elvyttää ja lujittaa alan tutkimusta, mikä osaltaan vahvistaa vapaan sivistystyön ja sen tekijöiden asemaa ja identiteettiä sekä ohjaa kehittämistoimintaa. Tätä pyritään toteuttamaan seuraavin keinoin:

1 luomalla yliopistojen ja vapaan sivistystyön organisaatioiden välille yhteistyöverkosto

1 syventämällä ja lisäämällä alan tutkimus- ja kehittämistyötä

1 turvaamalla mahdollisuudet tutkimuksen tekemiseen vapaan sivistystyön oppilaitoksissa

1 kokoamalla tutkimuksen tekemisestä kiinnostuneet yhteen

1 kartoittamalla tutkimustarvetta

1 tukemalla käynnistysprojekteja ja

1 hankkimalla tutkimukselle rahoitusta.

\section{Visio osana VSOP-ohjelmaa}

Vapaan sivistystyön yhteisjärjestö käynnisti hieman yli vuosi sitten keskustelun vapaan sivistystyön oppilaitoksille yhteisestä visiosta. Aiheesta on käyty laaja kenttäkeskustelu erilaisten tilaisuuksien ja internetin välityksellä. Keskustelun pohjalta on tuotettu kaksi vapaan sivistystyön visiota koskevaa asiakirjaa. Vision rakentamista jatketaan yhteisesti vielä vuoden 2000 loppuun saakka. Vision ei voida koskaan katsoa olevan valmis, vaan se jatkaa eloaan ja tarkentaa suuntaansa jatkuvasti. Onkin tarpeellista keskittyä visiointiin myös paikallistasolla. Sanat pitää muuttaa lähiyhteisöissä teoiksi ja todellisuudeksi.

Vapaan sivistystyön visiolla on useita keskeisiä tehtäviä. Visio antaa kasvot vapaalle sivistystyölle ja määrittää sen identiteettiä sekä suuntaa alan kehittämistä, koulutusta, tutkimusta ja rahoitusta. Oppilaitokset voivat suhteuttaa omat visionsa ja strategiansa yleiseen visioon. Visio on myös pohjana silloin, kun vapaan sivistystyön oppilaitoksia arvioidaan.

Lisää koulutuksesta: www.vsy.fi / VSOP

AIKUISKASVATUS 4/2000 